\title{
The Tropical-Urban Imagination: Ancestral Presences in Caribbean Literature
}

\author{
Hannah Lutchmansingh
}

The University of the West Indies, Trinidad

\begin{abstract}
This paper examines certain choices that Caribbean-born women make in forming and or rejecting connections to various foreign communities. Migration is examined as a stimulus to creative vision. By analyzing the literary evocations of Caribbean women's struggle with issues of displacement, refusal and their desire to find a place of their own, this paper explores the psycho-social impacts of empire and exile on black female bodies. In the selected narratives, there is the possibility for liberation that is afforded through a spatialization of memory, which bears the potential to confront and exorcise buried hurts and anxieties. As such, specific focus is given to the correlation between material and spirit dimensions in Erna Brodber's novel, Myal (1988) and Patricia Powell's short-story, "Travelling" (2015). The inquiry demonstrates how a return to timeless and all-pervasive ancestral presences may lead to an awakening from spiritual paralysis of essentialist and material ideologies. Moreover, the project scrutinizes how a comingling of carnal and divine realms influences woman's quality to forgive. This pursuit is achieved through a methodological approach of qualitative content analysis. Fittingly, it draws on mythic notions of time and collective memory, as espoused by Wilson Harris in The Womb of Space.
\end{abstract}

Keywords: Caribbean, literature, spirits, haunting, diaspora, identity 


\section{"Bridging Worlds": The Far Journey from Home}

$\mathrm{T}$

his paper looks at specific writings by Erna Brodber and Patricia Powell. It seeks to determine how these selected works frame and position migration within a quest for self-determination and self-discovery. Both writers descend or ascend into the world of spirits to explore how and why Caribbean peoples have yet to come to terms with the past and arrive at a position of certainty within our own landscapes. History is seen to be determining on this passage into self, but history may not in these works be viewed as chronological or linear. Instead both writers use Caribbean belief systems and their particular ideas of spirituality - defined in different ways and described in different ways - to enable a complex and deeply interiorized sense of how the past affects the present. In Brodbers' Myal (1988) the journey into the world of spirit leads to the creation of new myths through which the very facts of emancipation and nationhood are mythologized. This becomes a way of interrogating how the Caribbean survivor of enslavement has remained locked in the stasis of the past. The past and its capacity to cripple the psyche is also an important factor in the writings of Powell in her new short-story, "Travelling" (2015). This story relates directly to the spirit world as it moves within the unnamed protagonist and as it creates immobility to her personal encounters in the American, San Francisco city. There is thus a preoccupation with ancestral time or what may be referred to as a bridge between spaces. The story has a metamorphic form or mode as time zones, characters and even cultural contexts fade into each other.

Furthermore, what Brodber and Powell share most of all in their narratives is a profound excavation of the theme of migration. Their respective delineation of a woman-centred diaspora narrative provides a form of theoretical analysis. My intention is not necessarily to retrace or re-theorize the construction of the Afro-Caribbean Diaspora and Caribbean poetics in the historical sense. Several contemporary texts like Kamau Brathwaite's History of the Voice (1984), George Lamming's The Pleasures of Exile (1960), Curdella Forbes' From Nation to Diaspora (2005), Èdouard Glissant's Poetics of Relation (1997) and Silvio Torres-Saillant's Caribbean Poetics: Towards an Aesthetic of West Indian Literature (2013), among others, provide substantial scholarship and sociohistorical discussions on the subject. Evelyn O'Callaghan, for instance, makes thematic connections among Caribbean women writers like Erna Brodber, Jamaica Kincaid, Mary Prince, Frieda Cassin and Mary Seacole in her article, "'Home Away from "Home"?: The Migration Journey in Selected West Indian Fiction by Women" (2006). Yet, the focus is mainly on women's discursive positions of "in-betweenity" and ambivalence, which she argues constitute the essence of the West Indian condition. Further, O'Callaghan maintains that it is the process of creolization within the global village that continues to 
define the Caribbean region as a product or casualty of imperialism. The essay is predominantly a survey of the inclusive and exclusive nature of West Indian identity constructions in the diaspora. In that sense, O'Callaghan's concerns are categorically ideological. While there is an attempt to articulate the transcultural and paranormal dimensions of Brodber's Louisiana, there is not sufficient scope to generate a discussion that may be critically applied to the cosmological dimensions of the text where ancestral presences operate on the individual, communal and cross-cultural levels to release human beings from the stasis of materialist and capitalist greed. As such, this paper proposes a more evocative and spiritually-engaging reading of the ways that particular Caribbean women writers theorize black women's diasporic identity through a utilization of spirit presences, mythic time and an emblematic surreal narrative form. It submits a method that calls for a consciousness of accepting the manifestation of cosmic interrelatedness.

In that sense, the texts chosen for analysis advocate rejection of monolithic ways of being and seeing. History haunts the main characters in both narratives, and memories of home are a common theme. In Myal, Brodber utilizes African ancestral myalist traditions to make it inclusive and syncretic in order to reveal the possibility of escaping the legacy of colonialism by fighting "spirit thievery," the name she gives the psychological and spiritual devastation caused by colonialism's cultural imperialisms. In Powell's, "Travelling," the past, myths and spirits, both ancestral and otherwise, merge to recuperate the isolated and buried existence of the protagonist in the cold world of San Francisco.

The authors point delicately and obliquely at identity confusion and raise questions about the debilitating effects of received ideas and roles that the Caribbean person has inherited. By reading through the writers' characters, I will examine the question of how to uncover the Caribbean immigrant's struggle to construct an identity and a sense of belonging, while at the same time, coping with constraints of imposed identification by the host country. However, it is important to recognize that Caribbean peoples are already grappling with identity in the local island spaces. A Caribbean identity has always been difficult to articulate because the region resists categorization and containment as a result of its legacy of slavery and history of migration. Indeed, Stuart Hall, in his discussion of the Caribbean and cultural identity, speaks of the "right of separation," and the loss of identity resulting from slavery, which has been integral to the Caribbean experience (p. 394). Critic Carole Boyce Davies adds to this discourse when she characterizes Caribbean identities as "products of numerous processes of migration" (p. 13). Consequently, Caribbean immigrants, who are already dealing with 
the quandary of identity back home, are faced with a similar dilemma when they arrive in foreign spaces.

Focus is therefore given to those traces of home, which are etched in memory and which opens a new space for constructing an identity that simultaneously relates to home and the nation/host country. In that sense, home is no longer far away, but is within the reach. Drawing on Paula Morgan's panel presentation at the $36^{\text {th }}$ West Indian Literature Conference, where the scholar presents a spatio-temporal, theoretical frame of hinterland (diaspora) and heartland (local), this paper explores the unwritten personal experience of the migrant Caribbean woman, including but not limited to their oral, folklore and cultural habits, which comingle with modern conditions of isolation and unbelonging. Moreover, a portion of this argument seeks to give voice to the phenomena of Caribbean migrants who continue to circulate within the ambivalent, transcultural zone that evolved in the aftermath of empire. In the respective fictional universes, the haunting legacies of capitalism and slavery are enforced through racial and gendered segregation, which is felt on an individual level and mobilized in every day encounters.

\section{"The Infinite Rehearsal": Exploring the Cave of Ancestors}

The magical and enchanted fictional landscape that Powell utilizes are imbued with spirit mothers and fathers who act as restorative agents to the protagonist who carries the psychological 'inheritance' of negative self-image and alienation from her own indigenous culture. This harks back to Morgan's argument of the numerous and persisting burdens on women who live in the diaspora. Morgan cites sociologist Gutierrez-Rodriguez (2010) who notes that migrant women on the move are:

haunted by past intensities not always spelled out and conceived in the present. Immediate expressions and transmissions [...] may indeed revive repressed sensations, experiencesof pain or joy. Although not explicitly expressed as such, - [there] are temporal and spatial constellations of certain times, intricately expressed $[\ldots]$ in itineraries of the present/future (p. 5)

A part of Gutierrez-Rodriguez's argument hinges on the point that the forces, which materialize in the present-day may in fact be restless, clamoring submerged presences-be they repressed traumas and anxieties or ancestral spirit presences. Real or imagined, this device represents a life saver for the unnamed protagonist in Powell's, "Travelling". Spirits 
emerge throughout the fictional landscape and pit the young woman protagonist against a forested milieu in an attempt to reacquaint her with her forgotten ancient properties.

The tale found in Martin Munro's collection of ghosts stories entitled, The Haunted Tropics (2015), follows the trajectory of an unnamed female woman who flees Jamaica and migrates to the grey world of San Francisco where she becomes a high school teacher. Yet, despite her change in setting, there persists the cycle of having to care for things and for people, which recalls the burden of administering care to a dying grandmother back on the island. An examination of her setting tells of the depression and grim overtones that pervade her immigrant existence. Through her window, she daily observes and listens to the sound of the "mourning horn of a distant ship" (Powell, p. 35). The sea's movements symbolize the journeys that shape the psyche of Caribbean people: the arrival of colonists and slaves; the departures of their ancestors for 'better' lives elsewhere. Additionally, the connotation of water as utilized here, dovetails with the concept of migration and the fluidity of movement, which suggests displacement and uprootedness. In that token, Powell does not fail to emphasize the dominant themes of eroding roots and shifting ground, which she uses to illustrate that those historic roots and routes can never be completely erased for Caribbean people at home or in diaspora.

Not without apt coincidence, the protagonist's neurosis reaches its peak at nightfall as signposted by the visit of Ma Mait, her grandmother-spirit who transports her into a sublime and mythical jungle of ancestors. Here, the spirit mother enables the reader to make an incursion into time. This becomes a transition from linear time to mythic time, which opens a window into a different perception. This is achieved in the form of a chameleon-like language that utilizes Caribbean folk images and leitmotifs. The rhythm of the narrative is slow just as the journey is slow. Yet, the journey is made meaningful by the caresses of the visual imagery that woos the reader into compliance and comfort, not dissimilar to the easing of the child into the arms of a parent. Powell writes:

We leaped on the horse, my arms tight around Ma Mait's waist. [...]. Below us were the endless stretches of grassland, magic caves hidden inside the crevices of ravines, volcanic mountains [...]. [There were] endless roads that multiplied and divided, then appeared and disappeared into labyrinths. [...]. It was now deep into the night. A crescent moon hung from the sky. We nosed along the narrow edge of a forest swirling with spirits [...]. We stopped to rest under a tree (p. 30).

It is a story about the accommodation of the body to situations where it is better not to be resistant but to shift gears and fit into the tempo of the stream of existence itself. On certain 
occasions, the story requires that the reader accommodate and adjust to new rhythms of time and indeed of perception. These situations insist that we see differently. The story is at an overt level about space and the writer is concerned with the remapping of territory and with language as something that is shaped in the process of reterritorialization. Moreover, the concept of spirit mothers as generational beings and guides all points inexorably to the idea of continuity and healing. Ma Mait is more than a calm Sybil of fore knowledge; she is a teacher and the keeper of knowledge in a truly profound way. She provides the signposts to knowledge. But the path of true self-knowledge as the protagonist discovers, is beyond the simple process of being a follower of signs no matter how sure there are. True following, according to Powell requires obedience even in doubt.

Eventually, the narrator is left alone in the whimsical forest. She reflects, "Ma Mair had disappeared. It's okay, the horse said. I heard his voice with ears that were inside my chest. He could sense the panic" (p. 30). The doubt that envelops her is the doubt of a spiritual desert and aloneness, but it is also an echo of the lonesomeness of the transported slave who lacks full understanding of his or her situation in the new foliage of foreign landscape. This amnesic condition where memory is buried in the journey from Africa to the Americas is a condition of darkness. However, the recognition of this leads to a new journey, one that is a shaping of experience. The story is therefore embedded in the idea of individual and social change and contains a commitment to new responses in the face of transforming or challenging situations. In due course, she encounters her long-lost father, whom she never had the chance of meeting and who is now in part animal form. The vision of the bird faced man evokes the archetypes of the Egyptian Horus and Chichin feathered god, Quetzalcoatl. Powell is here opening the way for a more concerted and powerful expression of history that reflects a desire to be free of any form of caged imprisonment of spirit. Roland Barthes explores this tentative movement to release and its potential by suggesting that myths serve as a bridge to a reconnection with lost ancestors; it is "a signifying [repository of the raw] material" of our personal and human past (Barthes p. 110). The spirit-father's shape-shifting into an ancient, indigenous form of power is symbolic since he is the one chosen to expel the chaos of his daughter's identity. His potency as shaman climaxes when he offers her a sacred meal, which, when consumed, awakens her mind and senses. It signals a new birth and an opening into a new responsibility and a new terrain. Not long after, she receives a vision of a young couple dancing under the Caribbean sun and "running through a field full of white sage" (p. 33). The vision bespeaks a positive view of her family's history and the joy that her parents once shared. Within this epiphany, the antagonism which she once felt melts away.

Several points are quietly asserted here. The first is the point that the female experience of maturing, mothering, nurturing (as in the case of Ma Mait) already contains the ground of 
literature. This experience brings forth a new mood that dovetails with notions of homecoming and can be used in the description of far wider human experiences. It recalls the historical scenario of a people who have had to build from nothing and shape shift in order to survive, craft a language through assimilation and compromise, and who have shaped something new in the process. Originality in this sense does not pertain to the individual story or the individual race that produced it, but rather to an entire human race or commodity. These stories may be authenticated by the processes of the imagination which probes the past and incorporates the new. The form of the narrative then, is concerned with certain movements and paradoxes of time - circular movements, confusion between beginning and ending, past and future - which tend to give shape to the stories themselves. The creative imagination functions to retrieve and juxtapose different moments of lived experience.

Moreover, the story creates a narrative of woman's growth and her growing pains as she strives towards recognition of the limits of her world. Her quest occurs simply not in vision, but finds touchdown in the corporeal world as she returns to her apartment anew. She returns to her estranged fiancé, and he whispers to her, "Maybe we can try again" (p. 34). This, he confesses in context of mending their broken relationship. Powell therefore provides a new way of seeing. It is an effort to express an ethos that comprises mythic dimensions, which is, for the Caribbean, a way of life and being - one that holds within it a potential for exploring the rifts of women and men in the diaspora. The main character, however, cannot be reduced to any simplified formula. Although her life may seem complete to the regular passer-by on the San Francisco metropolis, something deep inside of her is about to be unleashed. This subconscious element is in fact the one piece of evidence that one needs to prove that she has some type of connection to her ancient island properties.

\section{Aesthetic Passages: The Half Has Been Told}

Erna Brodber's, Myal is also an orchestration of situations where the clash of history and migratory experience generates a new resonance. The paragraphs that follow focus on close readings of Myal where the novelist draws on the background of a pre-colonial Jamaica to shed light on the double-consciousness of Caribbean people living under colonial rule. Her work juxtaposes the protagonist's desire for belonging in the Baltimore land with reflections of a desire to be part of the foreign traditions that prevailed in the Caribbean where she lived. The social hierarchies of the colonial Caribbean islands are spatialized throughout the text which spans the years 1913-20 and Brodber paints the story of the mulatto protagonist, Ella O'Grady, whose zombification is as a result of the manner in 
which colonial forces have played out in her life. She is first noticed for reciting the Kipling poem, "Take Up the White Man's Burden." As the narrative progresses, she becomes the incarnation of the white man's burden, an important point which will be fully interrogated in the following paragraphs. This aspect of Ella's character is an example of the doubleconsciousness Caribbean people adopt in their homelands as they negotiate between the many vestiges of cultures, and which they often carry to the diaspora.

While at school, Ella had a tendency to mimic an English accent. It is important to note that this propensity for mimicking continues in America where she becomes an apparatus for her movie-producing husband in his exploits and production of the Caribbean landscape through his films. In retrospect, the colonial education consisting of a range of Kipling's poetry, in which she so willingly recites and meditates, renders Ella psychically raped. The colonial influence moves beyond daily living and into the girl's self-actualization. These circumstances create the spectral-like, internal voices within her mind. Her subsequent displacement and straddling of two worlds recalls the uprooting scenario of human beings from their homes unclothed and in chains, and who were transported over five thousand miles in degrading, painful and dangerous conditions. Yet, the worst of these empiric, scientific experiments in dehumanizing savagery were efforts to strip slaves of all human traits of decency, spirituality, honesty and respect by denying them the ability to worship and perform any activity that would support their inner life.

As aforementioned, Ella plays native informant to Selwyn Langley who strips her down to a cultural shadow in Baltimore. Appalled by what Langley has done to young Ella, Maydene is led to say, "spirit thievery comes in so many different forms" (p. 83). In the old line state, she becomes his star puppeteer in his debut shows. Devoid of real affection, she is an empty text to be written on as she undergoes a severe and prolonged form of psychical rape. Her role in Selwyn's, "Caribbean Nights and Days," spotlights Brodber's purposeful exploits of the parallels between her narrative and the myth of the decent middle-class young man motivated by capitalist greed. Selwyn's identity is framed and grounded in his own narcissistic reflection within a racialized social hierarchy. Ella's miserable existence reaches its peak during a viewing of one of the performances and she is paranoid that Selwyn has indeed distorted and misrepresented her island-heritage. She announces her displaced reality and utters in her colloquial twang, "It didn't go so" (p. 84). The heterodiegetic narrator comments that:

"Ella had told her stories well and Selwyn had listened well [...]. But this Grove Town in which Selwyn set his play, had to be the most fruitful place in the whole world and one which respected no seasons. There were breadfruits at the same time as there were star-apples as there were 
mangoes [...]. It was unnatural and it shook Ella" (p. 83). The expression has deep resonances with an identifiable socially, culturally and economically disenfranchised Caribbean minority who must confront rooted hostilities which outgrew from a history of fragmentation and loss. It comes as no surprise that when Ella resists further compliance in the shows, she is played with a toxic pregnancy. Western medicine cannot cure her somatic belly and she returns to Grove Town (Jamaica).

The island is depicted as a secret repertoire for psychic and physical restoration. However, the narrative exposition reveals that the islanders are adrift in a decaying landscape, which is a metaphor for Ella's septic pregnancy. A huge storm brewed, heralding her return and there were "banging and ringing and weeping" (3) on the galvanized tenements. According to Shalini Puri, "the trees [on the island] have memories and weep with the wounds of history" (p. 109). The immense threat of Ella's illness prompts the resurgence of the human-animal-ancestor overlay, in whose sage-like wisdom her cure lies. Maas Cyrus and company are summoned to Ella's rescue. They are the keepers of the root community who preside tacitly over Grove Town. Their concealed and underground network is revealed in an analysis of characters. Reverend Simpson, for instance, is Dan the mongrel while Ole African is Willie, the pig. Then there is Maas Cyrus who has the alter personalities of Percy and herbalist. Relishing in their physical disguise and bodily transformations, the myal spirits or conjure doctors reveal the political relationship between bodies of discourse, language and certainly history. That they span centuries, according to Puri, comes the revelation that their voices are, "mnemonic faculties submerged in the consciousness of alter egos [...]. The reader has little choice but to accept [...] the transhistorical nature of human spirit and its inherent link to an underlying cosmic circumstance" (p. 7). Fittingly, the intimacy of this spiritual network is articulated through the association of each character with an animal nickname. This becomes evident as the narrative occasionally steals away to surreal episodes of dialogue which highlight how the other-worldly presences in the text telepathically communicate with each other. It reflects Ole African's echoing parable that "the half has never been told" (p. 34-5). To that end, Brodber shuns realism and digs deep into language to find hidden mythological patterns which give significance to desperate situations. Yet, this argument is given without making totalizing cultural claims. Instead, the novelist combines afrocentrist and humanist ethics and aesthetics.

The myal spirits' transmutation into disembodied beings distills authority that ensures a continued sway or manipulation in socio-cultural and political structures. The narrative technique constitutes part of Brodber's methodology to free Caribbean discourse from the tyranny of one-sided assumptions. By depicting an alternative reality to be possessed, she invokes a vestigial collective unconscious who becomes an active participant in the mutual 
dialectic with each other and the world. Not unlike Powell's narrative, fragments from the past cease from being dead representations and appear as living figures which prompt social action. Their performance of 'going back to come forward' sets in motion the healing of the nation. The moment between worldly borders, between temporal layers and spaces, and the lack of clear markers seem to be wielded for the purpose of indirection for the reading audience. In both narratives, the reader must either reread or pause, or take notes, and piece the strands of narrative back together to create a coherent sense of exactly what happened, when, in what order, how and why. Readerly textual excavation is part of the narrative process. In that vein, both Powell and Brodber draw on Wilson Harris' notion of subjective time as experiments in memory, which he extensively describes in The Womb of Space (1983). Harris has identified what he calls the limbo imagination born of the rupture of space as it relates to the formation of the Caribbean and the residual traces of the ancestral past. These unconscious memories, according to Jean Antoine-Dunne, "attain a syncretic power in [Harris's] description of the limbo dance," where the dancer moves between the power pole, arching the body back into time and space and moves through "an unconscious map of memory" (p. 48). For Harris, memory is both process and becoming. Antoine-Dunne thus indicates that "literary work of art achieves an architectural structure through the evocation of [memory and myth] that both generates and release creative potential" (p. 48). In this sense, the writer becomes an alchemist and apprehends the fragments of memory and the displaced vestiges of culture to amass new knowledge. This produces a discursive type of writing, which is in service of developing a revisionary diasporic aesthetic that is used to break the mould of a one-sided narrative and to subvert the zombifying spiritual onslaught of colonialism and neocolonialism's hedonistic materialism.

In another recurring pattern, Brodber's narrative style, like Powell's, indicates a methodology that presumes the fusion of plants, animals, science, fossils, the human and spirit world. This literary arrangement serves as an apparatus of universes and cosmic planes-earthly and spiritual, above and below which seek to blend cross-cultural and cosmic dimensions. A return to African-Caribbean ceremonial spirituality thus rests at the heart of Brodber's text. In this mystical climate, the ghosts of history can be found. Spirit beings and their sage-like wisdom are revived, and what was otherwise sunken into oblivion are now central to the healing of the nation. Ella is treated through healing rituals that incorporate the use of chants, herbs and Afrocentric myalist practices. Represented then as syncretic force, conjure is an emancipatory tool. The narrator comments, "Whatever herbs [Maas Cyrus] had combined... worked well and within the time specified" (p. 95). The cure that he administers expels a "grey mass of muck," which "was like twenty thousand dead bull frog" (p. 4). The rotting mass that is exorcised from Ella's body recalls contemporary scenarios inclusive of but not limited to a threatening landscape of excess 
and of exoticizing a sexually charged and beautiful landscape that seemingly lays open to patriarchal rites of possession and conquest. Ella's treatment and attendant recovery affords her a place in the small group of conjure men and women who continue to work secretly to end colonization and other forms of oppression. She becomes a school teacher who is active in repairing the school curriculum that renders the children of Grove Town complicit in their own channels of zombification. Just as she had received the positive, curative benefits of myal, she feels motivated to right a wrong she sees as similar to her marriage to the Selwyn Langley. This she does by intervening in the colonial education system in Grove Town where the children are given up to a curriculum that is designed to do the same to them.

This brief analysis of both Brodber's and Powell's narratives, illuminates the manner in which Caribbean women writers re-negotiate the dynamics of resistance. These narratives reflect that dispersed throughout the islands and the diasporas are guiding ancestral presences, which, once evoked or remembered, enter like parts in a choral round that may return spiritual order. Not only are these timeless presences cultural apparatuses of power, but are keepers of traditions for their progenies. In this way, Caribbean writers of a spiritpoetics give rise to coeval modalities of unbroken connections with the past, through which new fellowships are imaged and futures are dreamed.

\section{References}

Antoine-Dunne, J. (2017). Words Are Not Enough. Journal of West Indian Literature, 25 (2), 48.

Barthes, R. (2013). Mythologies. New York: Farrar, Straus and Giroux.

Brathwaite, K. (1984). History of the Voice: The Development of Nation Language in Anglophone Caribbean Poetry. New Beacon.

Brodber, E. (2014). Myal. Long Grove, IL: Waveland Press, Inc.

Chen, K. (1996). "The Formation of a Diasporic Intellectual: An Interview with Stuart Hall." In David Morley and Kuan Chen (Eds). Stuart Hall: Critical Dialogues in Cultural Studies, pp. 394. London: Routledge.

Davies, C.B. (2002). Black Women, Writing and Identity: Migrations of the Subject. London: Routledge.

Forbes, C. (2005). From Nation to Diaspora: Samuel Selvon, George Lamming and the Cultural Performance of Gender. University of the West Indies Press.

Glissant, È. (1997). Poetics of Relation. University of Michigan Press.

Gutierrez-Rodriguez, E. (2010). Introduction: Sensing Domestic Work. In Migration, Domestic Work and Affect: A Decolonial Approach on Value and the Feminization of Labor, (p. 5). New York: Routledge. 
Harris, W. (1983). The Womb of Space. London: Greenwood.

Harris, W. (1999). Quetzalcoatl and the Smoking Mirror. In Selected Essays of Wilson Harris: The Unfinished Genesis of the Imagination, (p. 189). London: Routledge.

Lamming, G. (1960). The Pleasures of Exile. University of Michigan Press.

Morgan, P. (2017). Servant Mothering, Memory Work and Empathy in Olive Senior's "Pain Tree." $36^{\text {th }}$ West Indian Literature Conference on Affect and Ethical Engagement. St. Augustine: The University of the West Indies.

O'Callaghan, E. ((2006). "Home" Away from "Home"?: The Migration Journey in Selected West Indian Fiction by Women. In Caribbean Literature in a Global Context, (p. 64-103). St. Augustine: The University of the West Indies.

Powell, P. (2015). Travelling In M. Munro. (Ed.), The Haunted Tropics, (p. 27-36). Jamaica: The University of the West Indies Press.

Puri, S. (1993). An 'Other' Realism: Erna Brodber's Myal. A Review of International English Literature, 24,3, (p.109).

Rahming, M.B. (2001). Towards a Critical Theory of Spirit: The Insistent Demands of Erna Brodber's Myal. Revista/ Review Interamericana, 31,15, (p. 7).

Torres-Saillant, S. (1997). Caribbean Poetics: Towards an Aesthetic of West Indian Literature. Leeds: Peepal Tree. 